\title{
Determinants of Implementation SIAPIK for Small Medium Enterprise
}

\author{
I Gede Agus Pertama Yudantara ${ }^{1, *}$ Putu Yunartha Pradnyana Putra ${ }^{1}$ \\ Lucy Sri Musmini ${ }^{1}$
}

\author{
${ }^{1}$ Department of Economic and Accounting, Universitas Pendidikan Ganesha, Singaraja, Indonesia \\ ${ }^{*}$ Corresponding author. Email: agus.yudantara@undiksha.ac.id
}

\begin{abstract}
The purpose of this study is to predict and explain the behavioral intention of using SIAPIK by MSME actors. This study uses a questionnaire using a pick-up survey and e-mail survey. Respondents are 70 SMEs in Bali who have attended training or have used SIAPIK. Researchers used TAM where constructs were added. The results showed that Construct Behavioral Intention was influenced by Construct Perceived Usefulness, Construct Facilitating Conditions and Construct Subjective Norms where Construct Facilitating Conditions became the main determinant. Construct Perceived Ease of Use has no effect on Construct Behavioral Intention Behavioral Intention is influenced by Construct Perceived Usefulness, Construct Facilitating Conditions and Construct Subjective Norms where Construct Facilitating Conditions are the main determinants. Construct Perceived Ease of Use has no effect on Construct Behavioral Intention
\end{abstract}

Keywords: SIAPIK, SME, TAM.

\section{INTRODUCTION}

Indonesia is a country whose economy is developing. One of its characteristics is the growing number of small medium enterprises (SMEs). Bali is one of the provinces where the type of SMEs grows quite a lot. However, from the number of SMEs, it is undeniable that many SMEs do not register themselves for various reasons, such as taxes, other permits or the owners think that their business development is enough to get ther.

Bali Province, is a province where tourism is the main business sector. This tourism sector has led to the growth of many SMEs, both those that support tourism and are affected by the development of the tourism sector. In addition, there are also many SMEs that have grown outside the tourism sector which also contribute to the development of the Balinese economy. The contribution of them to income cycle in Bali economy has given its role, but for the ability to have competitiveness, the sustainability of growing and developing SMEs in the long term has not been able to be realized, because of the weakness of SMEs. One of them is capital [1]
The hedonistic character of millennials in Bali should be able to accelerate the growth of these SMEs. This means that there is a market opportunity that will accept the SME product. However, based on the results of observations from researchers, most SMEs in Bali lack capital and the capital they already have cannot be maximized because not many SMEs have the ability to manage their cash flow both for operations, financing and investment so that business continuity and growth business can occur so that SMEs can be said to be profitable

In capital adequacy needed by SMEs, especially SMEs in Bali, they usually get capital through Village Credit Institutions (LPD), Village Owned Enterprises (Bumdes), or cooperatives, sometimes loan sharks. However, during the COVID-19 pandemic, these nonbank financial institutions have problems with capital circulation for lending because many of their debtors were late in paying credit, some paid but mostly paid interest or did not pay both the principal and the interest.

Capital is indeed one of the problems faced by SMEs. However, because the SME sector is one of the strengthening of the people's economy in Indonesia, including in Bali Province through the Department of 
Industry, Trade, Cooperatives and Micro, Small and Medium Enterprises (Disperindagkop-UKM), this is be a concern for the government. It is necessary to know that SMEs are productive businesses if they are developed they will be able to support macro and micro economies [2]. Therefore, the central government and regional governments pay attention to the distribution of credit such as People's Business Credit (KUR) or Micro Business Loans distributed by banks.

SMEs in Bali are trying to obtain KUR or Micro Credit which is channeled through banks. One of the requirements to obtain credit is that SMEs must have financial statements. SMEs need to have financial reports related to their businesses which are required by the bank to provide business assistance to them, but SMEs face difficulties with these requirements. Financial reports are components that must be owned by SMEs if they want to develop their own business [3], including to obtain the capital adequacy.I

Observations show that the preparation of financial reports is a burdensome matter for SMEs. SMEs in Bali actually have human resources who are educated and have knowledge, but do not understand how to prepare standards financial reports. Financial reports, which are standard financial reports required by banks [4]. Many of the SME resources in Bali Province have come from Vocational High Schools (SMEA) or graduates from the economics faculty who are indirectly familiar with the basics of preparing financial reports. However, there are still doubts about human resources in preparing financial reports with standards, so SMEs in Bali Province prefer to pay for the services of financial consultants.

Currently, the resources of SMEs in Bali are already using technology with Microsoft Excel application tools to compile financial reports, but are still experiencing difficulties because of the ability to link sheets in Microsoft Excel. Because of it, sometimes transactions are compiled, grouped in the general ledger and financial statements are prepared, but financial statements that they compile, do not yet show the real performance and financial position of SMEs. Based on that, as one of the measures of financial literacy, Bank Indonesia introduced an application called the Financial Information Recording Application Information System (SIAPIK) which can help human resources in SMEs in Bali to prepare financial reports. SIAPIK is an application created by Bank Indonesia that can be downloaded for free and it is free to use on both mobile and computer devices.

For SMEs who have used SIAPIK either because of training or from tutorials and then compiling standard SME financial reports on the SIAPIK menu, it is said that they have the desire to use financial reports based on technology an application basis. Resources in SMEs in this study are called SME actors. SME actors in Bali Province use SIAPIK because they intend to do so [5].

Researchers see that the intention of SMEs to use SIAPIK is due to a belief from the perpetrators that by using SIAPIK, a standard financial report will be compiled which is indeed needed by banks, in addition to knowing about their financial position and business performance. In the initial observations, SMEs actors want to use SIAPIK, because SMEs belief that by using SIAPIK they will be able to record financial transactions, compile financial reports and analyze financial reports so that they believe that SIAPIK or financial information systems based on technology are useful [6]. In addition, SIAPIK has an easy-to-understand menu, so that this financial information system based on technology is easy to use by its users [7]

They want to use SIAPIK because the infrastructure or equipment needed to use SIAPIK is generally owned by SMEs. For example, a cell phone or computer device including the resources that run the equipment such as family or employees. However, before SMEs actors want to use SIAPIK, the role of fellow SMEs, SME players organizations, banks, and academics who provide training and assistance is the beginning of trust for SMEs actors to use SIAPIK. Based on the existing phenomena, this study focuses on the intentions and behavior of SMEs in using SIAPIK which is influenced by the perceived usefulness, perceived ease of use, facilitating conditions and subjective norms.

This study uses TAM be basic theory where the construct is added to the constructs of subjective norms and constructs facilitating conditions. Although the use of SIAPIK is not mandatory, researchers assume that SMEs want to use SIAPIK and accept SIAPIK. On this assumption, Technology Acceptance Model (TAM) is used by the researcher in this investigation. First, TAM is an information technology acceptance theory that takes into account psychological aspects. TAM, on the other hand, is a relatively simple but accurate model. Lastly, the TAM model provides a way for technology users to accept information technology systems. [8]. Fourth, previous researchers have used a good methodology in technology acceptance research so that it can be used as a theoretical basis for subsequent research [9] including TAM. 


\section{LITERATURE REVIEW \& HYPOTHESIS DEVELOPMENT}

SIAPIK application is a simple accounting application designed by Bank Indonesia for SME who have limitations in terms of the absence of accounting human resources, the absence of a desktop or laptop computer and the absence of fees for purchasing paid accounting applications or software. The advantage of this application lies in its simplicity, ease of operation, and is free of charge (free to download on playstore). By SIAPIK application, it is hoped that SMEs will be able to record financial transactions according to accounting standards. Financial record administration system for SMEs to increase capacity and facilitate access to banking. SIAPIK, which was developed by Bank Indonesia in 2014, is one of the instruments that can be used by SMEs to record financial transactions and prepare standard financial reports.

Perceived usefulness is the level of user confidence, namely SMEs, in increasing their activities [10] by using SIAPIK. The more useful this system is, the more people will want to use the SIAPIK spending system. This construct is directly related to the behavioral intention construct with indicators from the research of [11] namely (1) faster administration, (2) economic benefits; (3) Boost productivity, (4) efficiency, (5) make job easier

$\mathrm{H}_{1}$ : In the case of Small and Medium-Sized Enterprises, Perceived Usefulness of using SIAPIK has a positive influence on the Behavioral Intention of Using SIAPIK.

Perceived ease of use is the level of confidence of a person, namely SMEs in using a certain system [10] such as SIAPIK so that it will facilitate his work. The ease of using SIAPIK will increase user confidence in using this system. The TAM model and various TAM models explain the perceived ease of use construct, which is closely related to the behavioral intention construct. where the indicators used from the research of [12] are (1) There is no difficulty, (2 ) Easy, (3) Interaction that is easy to understand.

$\mathrm{H}_{2}$ : Intention to use SIAPIK by Small and Medium Enterprises is positively influenced by construct Ease of Use.

In order to use a system, a person must have faith that the necessary organizational and technical infrastructure is in place [13]. Their conditions are objective factors of viewers can agree to make a task easier for each other [14]. In this study, the facilitating condition is the extent to which SMEs believe that they have the resources to provide support when using SIAPIK. Research on [15] and [16]. The indicators of the facilitating condition were made easier by the inclusion of indicators and conditional construct statements in this study. Resources, expertise, and resources ready to assist in times of need are all examples of indications of the enabling condition construct that can be seen in action,

\section{$\mathrm{H}_{3}$ : Facilitating Conditions has positive influence on Behavioral Intention of using SIAPIK by Small Medium Enterprise}

Subjective norms are defined as a person's expectations from a specific reference of an individual or group, as well as their drive to meet those expectations [17]. In this study, subjective norms are defined as the expectations of trust and motivation placed on SMEs by others, which can impact their decision to generate financial reports using SIAPIK software. There is a clear relationship between this construct and the behavioral intention construct. This study uses indicators and subjective norm construct statement items from the research of [18] namely (1) Recommendations from fellow SMEs; (2) Recommendations from certain parties or communities; (3) Recommendations from academics; (4) Suggestions from social media

$\mathrm{H}_{4}$ : Subjective Norms has positive influence on Behavioral Intention of using of using SIAPIK by Small Medium Enterprise

\section{METHOD}

Population of this research is SMEs that have used SIAPIK either by attending training or SMEs that independently learn through tutorials about SIAPIK. There are many SMEs in the province of Bali and some SMEs already use information systems based on technology for the preparation of their financial reports, at least using a computer. Therefore, the population in this study is not known with certainty by the researcher. However, the researcher communicated with the Undiksha Entrepreneurship Laboratory so that an overview of SMEs was obtained that was already using SIAPIK.

Purposive sampling is a data collection strategy that selects a sample based on particular criteria. [19]. The criteria made cannot be separated from the results of observations and constructs built by researchers. The criteria include (1) the respondent has a SIAPIK account; (2) respondents input transactions using SIAPIK; (3) respondents prepare financial reports using SIAPIK; (4) respondents analyzed financial statements using SIAPIK; (5) respondents have attended training or received information about SIAPIK from certain parties; (6) respondents have prepared their financial reports for both internal and external parties. This means that respondents have applied SIAPIK in accordance with their business 
activities. Based on the criteria determined by the researcher, there are 70 SMEs that have received training and use SIAPIK.

Researchers employ survey methods to acquire data, specifically individual opinion data [20] and data suitable for large sample sizes [19]. This study included pick-up and email surveys. The researcher already knows the respondent's location to feel valued, and researchers can explain questions directly to them. The survey e-mail was sent to the UKM email where the researcher had communicated to ask for permission to carry out the research. Researchers used a questionnaire as a research instrument. The instrument is an instrument from previous research where the statement sentence is modified so that SMEs have no difficulty in providing answers to the statements submitted by the researcher. Researchers use instruments from research's [21], [22], [23], [24]

Researchers use Partial Least Square (PLS) as a data analysis tool because the purpose of this study is to predict and explain [25]. This study had a strong hypothesis effect because it was designed to test the validity of the TAM constructs and the constructs added to predict and explain the behavioral intention or desire of SMEs in using SIAPIK. The results of the PLS can be used to interpret it [25].

\section{RESULTS \& DISCUSSION}

To test the hypothesis, researchers must first determine the validity and dependability of the model. Each construct's average value extracted (AVE) and communality value (Communality) is greater than 0.5 in the table 1 , indicating that each indicator measures each construct independently or has already demonstrated convergent and discriminant validity, respectively. The Composite Reliability and Cronbach Alpha scores are more than 0.6, indicating that the construct indicators are accurate, error-free, and consistent.

It is possible to build a Goodness of Fit (GOF) formula to evaluate the inner model based on the value of R2, and it may be deduced that fit has been achieved when the relationship between components in the model can predict behavioral intents and usage behavior. In the following steps, the researcher investigated the hypotheses $(\mathrm{H}) 1,2,3$, and 4, and discovered if the t-statistic value was larger than 1,645 with a significance level of five percent ( 5 percent), the hypothesis was accepted. All of the hypotheses were supported, except for Construct Perceived Ease of Use on Construct Behavioral Intention, where the tstatistic value was less than 1645 , and the hypothesis was rejected.

\subsection{Perceived Usefulness and Behavioral Intention}

Based on the results of the Construct Perceived Usefulness test, it has a positive effect on Construct Behavioral Intention. This shows that there is a desire from SMEs to use SIAPIK. The results also show that SMEs believe in using SIAPIK because it provides benefits for SMEs. This is useful because the administration of using SIAPIK is easy and can be done quickly, for example, where they do not need to access a lot of personal data but by entering their Population Identification Number (NIK) and personal email or UKM email, they can already operate the SIAPIK

It is also useful because the system provides economic benefits and increases the productivity that will be obtained by them, for example with the product from SIAPIK in the form of financial reports whose presentation is in accordance with financial standards, MSMEs will independently be able to see the financial position of SMEs and the performance of SMEs. These things will of course increase the effectiveness and efficiency so that they are confident in using this system. This is what gives rise to their desire to use this information system

The results of this study are consistent with research [9], [23], [24] and [26] However, the results of this study do not support the results of the study [27] because they believe that there are benefits to be gained from the use of the information system. For example, trying to enter transactions according to real SMEs transactions, then being able to view ledgers and financial reports automatically, of course, making SMEs more interested.

\subsection{Perceived Ease of Use and Behavioral Intention}

The test results show Construct Perceived Ease of Use does not have a positive effect on Construct Behavioral Intention. 
Table 1. Output Quality Criteria Overview Algoritma

\begin{tabular}{|l|c|c|c|c|c|}
\hline & AVE & $\begin{array}{c}\text { Commu- } \\
\text { nality }\end{array}$ & $\begin{array}{c}\text { Croboach } \\
\text { Alpha }\end{array}$ & $\begin{array}{c}\text { Composite } \\
\text { Reliability }\end{array}$ & $\begin{array}{c}\text { R } \\
\text { Square }\end{array}$ \\
\hline Behavioral Intention & 0.693 & 0.794 & 0.775 & 0.871 & 0.629 \\
\hline Facilitating Conditions & 0.598 & 0.779 & 0.777 & 0.856 & \\
\hline Perceived Usefulness & 0.622 & 0.868 & 0.846 & 0.890 & \\
\hline $\begin{array}{l}\text { Perceived Ease of } \\
\text { Use }\end{array}$ & 0.699 & 0.794 & 0.785 & 0.874 & \\
\hline Subjective Norms & 0.717 & 0.870 & 0.868 & 0.910 & \\
\hline
\end{tabular}

This is because SMEs in using SIAPIK do not only see the ease of the system. Although this system is easy and not difficult which can indeed raise user confidence, the interaction between the SIAPIK system and SMEs cannot be carried out directly. Due to the lack of interaction between the system and the user, causing this easy and not difficult system, causing difficulties to arise. For example, when they enter your identity and type of business in the menu of SIAPIK.

Once SMEs as users enter real activities, it creates a lack of confidence because the transactions entered are appropriate which can later produce financial reports that are in accordance with the wishes of SMEs. Therefore, in using SIAPIK, direct interaction is also required by SIAPIK users. It should be noted that not all SMEs are actors with accounting or financial backgrounds, so there is a lack of confidence in using them. Therefore, the ease of the SIAPIK system but the lack of interaction causes the desire of SMEs to be less confident in using SIAPIK.

The results confirm research by [27] and [28]. The results of this study are not consistent with research results [24] because the lack of interaction of the system causes a lack of desire for SMEs to use this system.

\subsection{Facilitating Conditions and Behavioral Intention}

The results showed that Construct Facilitating Conditions had a significant positive effect on Construct Behavioral Intention. This construct is the main determinant in this research. Because SMEs have opinion that by using this system their level of trust will be higher. SMEs know that use SIAPIK do not require highly sophisticated equipment and a systematically integrated organization.

The resources that work in SMEs are usually high school/vocational or college graduates who have been taught computers. In addition, these resources are also used to using certain social media, so that in finding and learning SIAPIK, by using video tutorials. This means that it can be said that SMEs have knowledge about the benefits of using SIAPIK and have knowledge of using technology so that they have a desire to use SIAPIK.
In addition, the use of SIAPIK can be used on computers and mobile devices that are currently owned because computers are already widely owned where SMEs also need them. Owned cellular phone also includes a smart phone that can install SIAPIK easily. This increases user confidence in using this system so that they want to use SIAPIK. Because of the benefits of financial reporting that is in accordance with standards, this is also conveyed to several SME communities so that SMEs who have used or have not used SIAPIK are willing to use SIAPIK.

It is consistent with research conducted by [29] and [30]. The results of this study are not consistent with research results [27]. However, if SMEs already have the resources, they need they will naturally want to use the system.

\subsection{Subjective Norms and Behavioral Intention}

The test results show that Construct Subjective Norms have a positive effect on Construct Behavioral Intention. This means that the desire of SMEs to use SIAPIK is influenced by recommendations or suggestions from other parties. This other party, of course, has already used and on his advice to certain SMEs has an influence on the desire of these SMEs to use this system.

SME colleagues, whether in similar businesses or not, provide recommendations either directly or indirectly to other SMEs when using this system that it does not require very sophisticated equipment but is able to produce the required financial reports. The SME community or certain parties such as banks who know information about SIAPIK also play a role in influencing the desire of SMEs to use this system. Mentors or training companions during the mentoring process from universities also have an influence, especially suggestions if there are problems in using SIAPIK. Social media is also a reference for suggestions for SMEs so that they have the desire and use this system to make financial reports.

This means that other parties also have an influence on the desire of SMEs to use this system. The results of this study are consistent with research results [18], [31], and [32]. The results of this study are not consistent with 
research results from [33]. However, the researcher argues that other parties certainly have an influence because they provide suggestions so that SMEs want to use this system. Overall, the constructs in this study cab be shown in Figure 1.

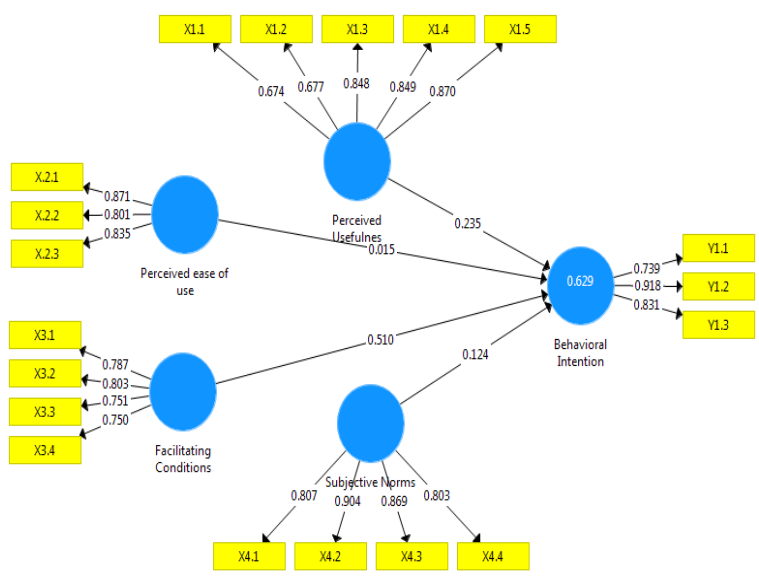

Figure 1. PLS Algorithm

\section{CONCLUSION}

First, Construct Behavioral Intention is influenced by Construct Perceived Usefulness, Construct Facilitating Condition and Construct Subjective Norms. This means that SMEs are willing to use SIAPIK because SIAPIK is useful, SIAPIK does not require very sophisticated technology, resources and equipment and SIAPIK is also always recommended by other parties who wish to increase the value of SMEs, one of which is the existence of financial reports that are in accordance with standard.

Second, Construct Perceived Ease of Use does not have a positive effect on Construct Behavioral Intention. This means that although SIAPIK is easy and not difficult, because of lack of system interaction, it causes a lack of confidence in SMEs in using SIAPIK. Third, Construct Facilitating Conditions are the main determinant, meaning that SMEs in Bali already have the resources and equipment that can use SIAPIK so that SMEs have desire to use the system. Fourth, the constructs added to TAM can predict the desire of SMEs actors to use SIAPIK.

The suggestions that can be submitted are, first, for Bank Indonesia which aims to provide financial literacy and digital literacy for SMEs through SIAPIK, it is necessary to pay attention to the role of other parties in digital literacy and financial literacy, because SMEs still lack confidence in using SIAPIK, due to the lack of interaction between system with users so that the role of other parties who introduce, provide training and assist especially academics who have been trained in SIAPIK will be able to help motivate SMEs in using SIAPIK.
Second, most SMEs in Bali already have equipment and resources so that SMEs through communities or organizations where SMEs take shelter, SMEs that have received SIAPIK training or organizations or communities invite practitioners or academics who have received training as SIAPIK mentors as parties who help socialize , training and mentoring on the use of SIAPIK for other SMEs so that MSMEs can have financial reports that comply with standards. This shows the role of outsiders is very necessary..

Third, for further research, the Construct System Quality can be used because the system built by Bank Indonesia has good quality, but it is necessary to examine its effect on desire of SMEs in using SIAPIK. Researchers also have not examined the direct actions of SME actors in using SIAPIK because it is necessary to require at least that SME have presented financial reports to external parties using SIAPIK.

\section{AUTHORS' CONTRIBUTIONS}

The three of us contributed to this article I Gede Agus Pertama Yudantara as coordinates research and article writing activities. Putu Yunartha Pardanyana Putra helped with the preparation and data collection. Lucy Sri Musmini the research data analysis.

\section{ACKNOWLEDGMENTS}

We are grateful to Universitas Pendidikan Ganesha especially the LPPM Undiksha and the Faculty of Economics for your support so this article can be realized.

\section{REFERENCES}

[1] H. Wibowo, “Analisis Pengaruh Persepsi Permodalan Terhadap Kinerja Usaha dalam Meningkatkan Keberhasilan UKM," Kompartemen J. Ilm. Akunt., vol. 18, no. 2, 2020.

[2] Y. R. Suci, "Perkembangan UMKM (Usaha mikro kecil dan menengah) di Indonesia," J. Ilm. Cano Ekon., vol. 6, no. 1, pp. 51-58, 2017.

[3] M. Susanto and R. Nuzul Ainy, "Penyusunan laporan keuangan usaha mikro kecil menengah berdasarkan sak emkm (studi kasus di umkm fresh fish bantul)." Universitas Ahmad Dahlan, 2019 .

[4] I. M. Narsa, A. Widodo, and S. Kurnianto, "Mengungkap kesiapan UMKM dalam implementasi standar akuntansi keuangan entitas tanpa akuntabilitas publik (PSAK-ETAP) untuk meningkatkan akses modal perbankan," J. Ekon. dan Bisnis Airlangga, vol. 22, no. 3, 2012.

[5] I. Im, S. Hong, and M. S. Kang, “An international 
comparison of technology adoption: Testing the UTAUT model," Inf. Manag., 2011, doi: 10.1016/j.im.2010.09.001.

[6] C. Liao, P. L. To, and C. C. Liu, "A motivational model of blog usage," Online Inf. Rev., 2013, doi: 10.1108/OIR-02-2012-0032.

[7] R. Purwaningsih and B. Adison, "Path analysis method to identify factors affecting consumer interest on online shopping," 2017, doi: 10.1109/ICSITech.2016.7852601.

[8] H. M. Jogiyanto, "Sistem informasi keperilakuan," Yogyakarta Andi Offset, 2007.

[9] I. G. A. P. Yudantara, N. L. G. E. Sulindawati, and G. A. Yuniarta, "Analysis use of academics information system by Undiksha new student," 2019.

[10] F. D. Davis, "Perceived usefulness, perceived ease of use, and user acceptance of information technology," MIS Q. Manag. Inf. Syst., vol. 13, no. 3, pp. 319-339, 1989, doi: 10.2307/249008.

[11] M. A. Bonn, W. G. Kim, S. Kang, and M. Cho, "Purchasing Wine Online: The Effects of Social Influence, Perceived Usefulness, Perceived Ease of Use, and Wine Involvement," J. Hosp. Mark. Manag., vol. 25, no. 7, pp. 841-869, 2016, doi: 10.1080/19368623.2016.1115382.

[12] S. A. Nikou and A. A. Economides, "Mobilebased assessment: Investigating the factors that influence behavioral intention to use," Comput. Educ., vol. 109, pp. 56-73, 2017.

[13] V. Venkatesh, M. G. Morris, G. B. Davis, and F. D. Davis, "User acceptance of information technology: Toward a unified view," MIS $Q$., pp. 425-478, 2003.

[14] R. L. Thompson, C. A. Higgins, and J. M. Howell, "Personal computing: Toward a conceptual model of utilization," MIS $Q$., pp. 125-143, 1991.

[15] S. S. Al-Gahtani, G. S. Hubona, and J. Wang, "Information technology (IT) in Saudi Arabia: Culture and the acceptance and use of IT," Inf. Manag., vol. 44, no. 8, pp. 681-691, 2007.

[16] L. Abdulwahab and Z. M. Dahalin, “A conceptual model of Unified Theory of Acceptance and Use of Technology (UTAUT) modification with management effectiveness and program effectiveness in context of telecentre," African Sci., vol. 11, no. 4, 2021.

[17] M. Fishbein and I. Ajzen, "Belief, attitude, intention, and behavior: An introduction to theory and research," Philos. Rhetor., vol. 10, no. 2, 1977.
[18] M. H. Moshrefjavadi, H. Rezaie Dolatabadi, M. Nourbakhsh, A. Poursaeedi, and A. Asadollahi, "An Analysis of Factors Affecting on Online Shopping Behavior of Consumers," Int. J. Mark. Stud., vol. 4, no. 5, 2012, doi: 10.5539/ijms.v4n5p81.

[19] M. P. P. Sugiyono and P. Kuantitatif, "Kualitatif, dan R\&D, Bandung: Alfabeta,” Cet. Vii, 2009.

[20] H. M. Jogiyanto, "Pedoman survei kuesioner: Mengembangkan kuesioner, mengatasi bias dan meningkatkan respon," Badan Penerbit Fak. Ekon. dan Bisnis UGM. Yogyakarta, 2008.

[21] R. Septiani, P. W. Handayani, and F. Azzahro, "Factors that affecting behavioral intention in online transportation service: Case study of GOJEK," Procedia Comput. Sci., vol. 124, pp. 504512, 2017.

[22] L. Winata, D. Permana, J. M. S. No, and J. B. Indonesia, "The effect of electronic coupon value to perceived usefulness and perceived ease-of-use and its implication to behavioral intention to use server-based electronic money," Int. J. Innov. Sci. Res. Technol., vol. 5, no. 1, pp. 147-158, 2020.

[23] I. G. A. P. Yudantara, L. S. Musmini, I. P. G. Diatmika, and G. A. Yuniarta, "Analysis of Acceptance and Success Implementation of Academic Information System (SIAk) Based on Technology,” 2019.

[24] I. G. A. P. Yudantara and I. N. P. Yasa, "Determinant Use of Behavior Online Shopping Information System," in 5th International Conference on Tourism, Economics, Accounting, Management and Social Science (TEAMS 2020), 2020, pp. 413-419.

[25] J. Hartono and W. Abdillah, "Konsep dan Aplikasi PLS (Partial Least Square) Untuk Penelitian Empiris," Ed. I, BPFE, Yogyakarta, 2009.

[26] W. D. Neill and J. E. Richard, "Intranet portals: Marketing and managing individuals' acceptance and use," Australas. Mark. J., vol. 20, no. 2, pp. 147-157, 2012, doi: 10.1016/j.ausmj.2011.10.003.

[27] A. Tarhini, A. Al-Badi, M. Almajali, and S. H. Alrabayaah, "Factors Influencing Employees; Intention to Use Cloud Computing," J. Manag. Strateg., vol. 8, no. 2, pp. 47-62, 2017.

[28] K. Dou et al., "Patients' acceptance of smartphone health technology for chronic disease management: a theoretical model and empirical test," JMIR mHealth uHealth, vol. 5, no. 12, p. e7886, 2017. 
[29] N. K. R. D. Putri and I. M. S. Suardikha, "Penerapan Model UTAUT 2 Untuk Menjelaskan Niat Dan Perilaku Penggunaan E-Money di Kota Denpasar," Sumber, vol. 232, p. 971, 2019.

[30] H. Sung and J.-I. Shin, "The Effect of SelfEfficacy on Behavioral Intention through Expectancy, Social Influence, and Facilitating Conditions in Mobile Learning: The Moderating Effect of Gender," 인터넷전자상거래연구, vol. 17 , no. 2, pp. 39-52, 2017.

[31] T. H. Lan Ho and Y. Chen, "Vietnamese Consumers' Intention to Use Online Shopping: The Role of Trust," Int. J. Bus. Manag., vol. 9, no. 5, pp. 145-159, 2014, doi: 10.5539/ijbm.v9n5p145.

[32] S. Yang, L. Li, and J. Zhang, "Understanding consumers' sustainable consumption intention at China's Double-11 online shopping festival: An extended theory of planned behavior model," Sustain., vol. 10, no. 6, 2018, doi: 10.3390/su10061801.

[33] J. Liu, G. Li, H. Li, and Z. Wang, "Planned Behavior Theory-based Study on the Influencing Factors in Construction Waste Reducing Willingness_-with Construction Workers as an Example," Ekoloji, vol. 26, no. 102, pp. 13-28, 2017. 